\title{
事業継続のためのリスクファイナンス手法の提案 \\ PROPOSAL OF RISK FINANCING METHOD TO SECURE BUSINESS CONTINUITY
}

\author{
西川 智*, 福島 誠一郎**, 矢代晴 実*** \\ Satoru NISHIKAWA, Sei'ichiro FUKUSHIMA and Harumi YASHIRO
}

\begin{abstract}
Securing immediate funding for business recovery is indispensable for minimizing economic damage by sudden disasters. The Japanese Government recently issued a set of business continuity \& disaster preparedness guidelines where it calls for businesses to plan for quick resumption of operations. There are some existing methods for risk financing, for example, earthquake insurance and alternative risk transfer (hereinafter called ART). However, there is still room for better risk financing methods to be developed. In this paper, the pros and cons of existing risk financing methods are examined. A new method is proposed, combining features of earthquake insurance and parametric triggered ART with focus on minimizing basis risk. A model portfolio of 10 building assets in Tokyo Metropolitan area was applied in analyzing the performance of this method. Through the application, the following findings were obtained; this method allows sufficient risk transfer as provided by earthquake insurance and also enables immediate funding, compared to existing ART methods this method enables lowering the cost by risk takers, hence, this method is attractive for both the recipient and the risk takers and has good possibility to be a new tool for risk financing.
\end{abstract}

Keywords: Business Continuity, Seismic risk, Risk financing, Parametric Trigger, Basis risk 事業継続，地震リスク，リスクファイナンス，パラメトリックトリガー, ベーシスリスク

\section{1.はじめに}

平成 17 年 8 月, 事業体の減災と災害対応の向上を目的として, 内 閣府より「事業継続ガイドライン 第一版」 ${ }^{1}$ が示された。同ガイド ラインでは, 人命の確保，二次災害の防止を前提としながら，事業体 が事業継続に取り組むことの主旨と論点が説かれている。

事業継続への具体的な取り組みは事業体に依存する。全国各地ある いは全世界に事業展開している事業体に対しては,多地域でのリスク 分散や被災地での事業撤収という選択肢が存在するが, 操業地域が限 定されている事業体にとっては, 被災地での早期操業開催を選択せさ るを得ない。このような事業体としては，鉄道，電力，ガス，水道と いった地域独占型サービス業，ホテル，ショッピングセンターといっ た商圈を有する業種，さらには，地域独占サービス業である自治体が 挙げられる。

さて, 災害被災後の業務再開の上で, 資金調達は常に大きな課題で ある。十分な資産を保有しているにも関わらず，運転資金が確保でき ないために事業体が倒産したという事実は, 阪神・淡路大震災の際に も見られた。言い換えるなら，被災後の資金調達が迅速かつ安定した 形で確保できるならば, 経済被害の拡大を最小限に留めることができ ると考えられる。

自然災害リスクを含むりスク全般に対する経済的な補填は,リスク
ファイナンスと呼ばれ，損害保険に代表されてきた。地震りスクに対 しては地震保険注 ${ }^{1)}$ がその役を担ってきたが，損失の見積もりに時間 を要することや引き受けキャパシティの制限により, 迅速かつ安定的 という観点からは, 被災後の業務再開に十分対応することができない 場合もある。

ところで, 近年では金融工学の発展に伴い, 自然災害りスクのへッ ジに関しても，保険市場以外に原資を求めることや，損失以外の支払

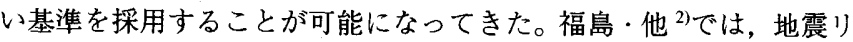
スクを証券化することで，損失補填の原資を資本市場に求めている。

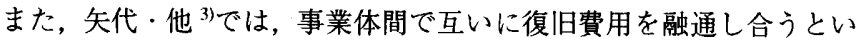
うリスクスワップ手法を提案している。これらの検討事例においては, 支払い基準として, 地震の発生位置と地震規模等の客観的な值 (以下, パラメトリックトリガー) を用いており, 補填額の評価に透明性と迅 速性を与えている。

一方,パラメトリックトリガーを用いるリスクファイナンス手法に は，実際の損失と補填額との乘離によるリスク（以下，ベーシスリス ク）が存在する。矢代・他 ${ }^{4)}$ では, ベーシスリスクによる不利益を, 不十分な補填に伴うリスクと,過度な補填に伴うリスク対策コストに 大別し、これらが互いにトレードオフの関係にあることを示している。 また,そのために地震保険に比べてリスクヘッジに要する費用が割高
* 内閣府(防災担当) 工修

** 東電設計(侏) 博士 (工学)

*** 東京海上日動リスクコンサルティング侏) 博士(工学)
Cabinet Office (Disaster Management), M. Eng.

Tokyo Electric Power Services Co., Ltd., Dr. Eng.

The Tokio Marine \& Nichido Risk Consulting Co., Ltd., Dr. Eng. 
であり，普及の阻害要因となっている。

そこで, パラメトリックトリガーを用いながら, ベーシスリスクを 小さく留めるようなリスクファイナンス手法が塞現されれば, その普 及によって災害時の経済損失の拡大を防ぐことが可能となり, 事業体 の事業継続の確保に繋がると考えられる。

本研究では以上を鑑み，損失に基づくトリガー（以下，損失トリガ 一）とパラメトリックトリガーの両者の特徴を有するリスクファイナ ンス手法を提案・構築するとともに, 当該手法をモデル事業体のリス ク評価に適用し，その有効性を検討する。

\section{2. リスクファイナンスの概要}

2.1 リスクマネジメントにおけるリスクファイナンスの役割

日本でリスクマネジメントを行う場合, 耐震補強等の事業プロセス の改善に関心が偏りがちであるが，欧米で見られるように，事業体の 抱えるリスクが顕現化することに伴う経済的損失を如何にコントロ ールするかということも,リスクマネジメントの一環として重要な経 営課題である。

リスクファイナンスの発想は, 事業プロセスの改善によっても排除 しきれないリスクについて手当を実施するというものである。すなわ ち,リスクファイナンスは, 残余りスクが顕現化し, 財務的損失が発 生した場合でも，事業体財務の健全性を維持するための金融・財務的 手法である。事業体はリスクファイナンスに取り組むことで, 将来発 生するかもしれない財務的損失を一定の予想の範囲内に収める可能 性を高めることが出来るようになり，この結果として事業体の期間損 益の平準化を図ることが可能となる他, 倒産という最悪の事態を回避 することも可能になっていると考えられる。

\section{2 リスクファイナンス手法}

冒頭に述べたように，損害保険は事業体のリスクファイナンス手法 の一つとして重要な役割を果たしてきた。ただし，損害保険の市場の キャパシティは資本市場の規模と比べて小さいため,リスクによって は保険のキャパシティが急激に縮小したり,再保険料が激しく変動し たりする場合も少なくなく,支払い保険料の平準化を通じた効率的な リスクファイナンスが行えないという指摘がある。とりわけ，昨今の 自然災害やテロ等の頻発による保険金の支払い増に伴い,このような ことが顕著に現れてきており，特に日本の地震リスクについては，保 険会社の引き受けキャパシティは限定的になってきている。この結果, 日本において二ーズの高い地震保険に対して,十分な対応ができてい ないのが実情である。

一方，一部の事業体では，より効率的にリスクファイナンスを行う ため, 従来型の保険契約以外のリスク移転手法(以下, ART, Alternative Risk Transfer：代替的リスク移転）を活用しつつある。これまでのよ うに単にリスクを保険会社に付保するのみならず,リスクの特性, リ スク保有コスト・移転コストを勘案し，リスクを自己保有するか外部 移転するか，あるいは，リスクの移転先として保険会社・保険市場を 活用するか資本市場を活用するかを検討し，複数の手法を組み合わせ て，リスクファイナンスを実施する動きが見られる。

デリバティブの活用により事業体が抱えるリスクを資本市場に移 転することで，保険市場でキャパシティ不足となっているリスク（自 然災害等)やリスクの特性上保険会社への付保が困難なりスク（地震

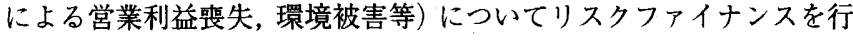
うことが可能となる。表 1 に各リスクファイナンス手法を概括する。 ART の活用において最もポピュラーなのが, リスクを証券化し CAT ボンド (Catastrophe Bond) と呼ばれる証券を資本市場で発行す るものである。その優位性として, 証券化によりリスクの小口分散を 図ることができること，保険がカバーする直接損害（工場の損壊等） だけでなく，間接損害（地震による事業の中断等）にも対応できるこ と, 資金の支払いが迅速であること等が挙げられる。また, 資本市場 は投資家の厚みもあり相対的に資金量も豊富となっており（因みに， 東証一部の時価総額は 400 兆円程度)，同市場にアクセスすることに より，多様なりスクを機動的に分散することが期待できる。

また，デリバティブの活用としては，一部でスワップを活用してい る事例が見られる他，米国シカゴ取引所では「災害指数」を利用した オプションが取引されている。

表 1 自然災害リスクの金融的な処理方法

\begin{tabular}{|c|c|c|c|}
\hline $\begin{array}{l}\text { 分 } \\
\text { 類 }\end{array}$ & 方式 & 方法 & 処理内容 \\
\hline \multirow{5}{*}{$\begin{array}{l}\text { 事 } \\
\text { 菜 } \\
\text { 部 } \\
\text { 章 } \\
\text { 少 } \\
\text { 屓 } \\
\text { 担 }\end{array}$} & 自家保有 & 無保険 & 損失を当年度利益で吸収 \\
\hline & $\begin{array}{l}\text { 遡及的料率 } \\
\text { 算出方法 }\end{array}$ & 保険契約 & $\begin{array}{l}\text { 損失を次年度以降の会計年次へ } \\
\text { 分散し，各年度の利益で吸収 }\end{array}$ \\
\hline & $\begin{array}{l}\text { 他年度拘束 } \\
\text { 保険契約 } \\
\end{array}$ & 保険契約 & $\begin{array}{l}\text { 損失を次年度以降の会計年次へ } \\
\text { 分散し，各年度の利益で吸収 }\end{array}$ \\
\hline & $\begin{array}{l}\text { キャプティブ } \\
\text { 保険会社 }\end{array}$ & $\begin{array}{l}\text { 保険契約 } \\
\text { 再保険契約 }\end{array}$ & 子会社の株主資本で吸収 \\
\hline & $\begin{array}{l}\text { 融資予約 } \\
\text { 方式 } \\
\end{array}$ & 融資契約 & $\begin{array}{l}\text { 長期借入金でキャッシュフロー } \\
\text { を確保（長期負倩として処理） } \\
\end{array}$ \\
\hline \multirow{6}{*}{ 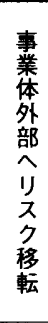 } & $\begin{array}{c}\text { 非常時劣後債 } \\
\text { 発行権 } \\
\end{array}$ & 倩権発行 & 株主へのリスク移転 \\
\hline & $\begin{array}{l}\text { 非常時株式 } \\
\text { 発行権 }\end{array}$ & 增資 & 株主へのリスク移転 \\
\hline & 保険 & 保険契約 & 保険市場へのリスク移転 \\
\hline & 共済 & 共済加入 & 井済組合員へのリスク移転 \\
\hline & デリバティブ & 金融取引 & $\begin{array}{l}\text { 金融派生商品（デリバティブ）市 } \\
\text { 場へのリスク移転 }\end{array}$ \\
\hline & 証券化 & 証券取引 & 資本市場へのリスク移転 \\
\hline
\end{tabular}

3. ベーシスリスクに着目したリスクファイナンス手法の提案 3.1 ベーシスリスクの定義

リスクファイナンスを実施するには費用（以下，リスクコスト）が 伴う。経常利益の変動として吸収できるような高頻度・低額の損失に 対してリスクコストを費やすことは合理的ではなく，一方, 巨額の損 失に対して全額を補填することは, 極めて大きなりスクコストに繋が るため, 現害的ではない。したがって, 地震保険のように, 免責額と 引受限度額で規定される支払方法がリスクファイナンスにおいて合 理的である。そこで, 次式に示すように, 損失トリガーで与えられる 補填額を参照補填額とし，これとパラメトリックトリガーで与えられ る補填額との乘離をべーシスリスクとして定義する。

$$
\begin{aligned}
& B R_{1}=L_{c}-L_{c}^{*}, \text { if } L_{c}^{*}<L_{c} \\
& B R_{2}=L_{c}^{*}-L_{c}, \text { if } L_{c}^{*}>L_{c}
\end{aligned}
$$

ここで， $L_{c}$ は損失トリガーで与えられる補填額， $L_{c}^{*}$ はパラメトリ ックトリガーで与えられる補填額である。 $B R_{1}$ は $L_{c}^{*}<L_{c}$ となる場合 のベーシスリスクで, 所定の補填が行われないことに対応する。すな 
わち，リスクヘッジを行う事業体のリスクとなる。一方， $B R_{2}$ は $L_{c}^{*}>L_{c}$ となる場合のベーシスリスクで, 過度の補填が行われること に対応する。これは事業体のリスクの移転先が負うリスクであり，そ の大きさに見合ったリスクコストが事業体に発生する。

$B R_{1}$ と $B R_{2}$ は，その定義により互いにトレードオフの関係にある。 そのため,リスクマネジメントの目的から $B R_{1}$ をある程度小さく抑え るためには，BR 2 は大きくならざるを得ない。

\section{2 提案するリスクファイナンス手法}

災害直後の資金調達の観点からパラメトリックトリガーを採用す るため， $B R_{1}$ は不可避である。 $B R_{1}$ を従来手法と同程度に維持しなが

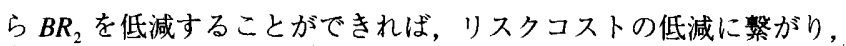
より合理的なりスクファイナンスの実現が可能になると考えられる。 そこで，本研究では次式に示すような補填方法を提案する。

$$
\begin{array}{lll}
L_{c}^{* *}=L_{c}^{*} & \text { if } L_{c}^{*}<L_{c} \\
L_{c}^{* *}=L_{c}^{*}-r \cdot\left(L_{c}^{*}-L_{c}\right) & \text { if } L_{c}^{*}>L_{c}
\end{array}
$$

ここで， $L_{c}^{* *}$ は提案手法による補填額である。また， $L_{c}^{*}<L_{c}$ の場合に は，パラメトリックトリガーで規定される補填額となる。 $L_{c}^{*}>L_{c}$ の 場合には, $L_{c}^{*}$ と $L_{c}$ の差額に係数 $r$ を乗じた値をパラメトリックトリ ガーで規定される補填額から減じた額が補填される。 $r$ は減額分を規 定する変数で,この新しいリスクファイナンス契約を締結する際に予 め定めるものである。 $r=0$ ならば従来のパラメトリックトリガーに よる補填に，r=1ならば損失トリガーによる補填に相当する。

$(1 b)$ 式が不必要な補填までを行わざるを得ないのに対し，(2b)式は 必要な補填のみを行うことができる。すなわち，前者は先物取引的な リスクファイナンスであり, 後者はオプション取引的なリスクファイ ナンスであると考えることができる。

また， $(2 b)$ 式は，次式のように書き換えることができる。

$$
L_{c}^{* *}=L_{c}+(1-r)\left(L_{c}^{*}-L_{c}\right) \quad \text {,if } L_{c}^{*}>L_{c}
$$

(3)式の右辺第 2 項は， $L_{c}^{*}>L_{c}$ という条件で, パラメトリックトリガ 一に損失トリガーの振る舞いをさせるときの余㮃な補填額であり,損 失トリガーに対するパラメトリックトリガーのコスト増の 1 つの要 因である。

$(2 b)$ 式が示すように， $L_{c}^{*}>L_{c}$ の場合の補填額の設定には $B R_{2}$ の評 価が必要となる。そのため, 害際の運用においては, 災害発生直後に $L_{c}^{*}$ を徵収し， $L_{c}$ の見積もりが終了した段階で $r \cdot B R_{2}$ を返却するとい う 2 段階の手順が必要になる。(2)式の補填方法を採用した場合, ベ ーシスリスクは次式のように求められる。

$$
\begin{array}{lll}
B R_{1}=L_{c}-L_{c}^{* *}=L_{c}-L_{c}^{*} & \text {, if } L_{c}^{*}<L_{c} \\
B R_{2}=L_{c}^{* *}-L_{c}=(1-r)\left(L_{c}^{*}-L_{c}\right) & \text {, if } L_{c}^{*}>L_{c}
\end{array}
$$

$(4 a)$ 式は, 定義により $(1 a)$ 式そのものであり，(4b)式は, $(1 b)$ 式に $(1-r)$ を乗じたものとなっている。また， $r=1$ とした場合には, ベーシス リスクは発生しない。

なお， $B R_{1}$ についても $B R_{2}$ と同様に， $L_{c}$ の見積もりが終了した段 階で不足補填額を追加徵収するという手法が考えられるが, リスクフ アイナンスの目的が被災後の即時性の高い資金調達であることから， 本研究では検討外とした。
3.3 リスクファイナンスを考慮した地震リスク定量化の手順

筆者らは, 多数の想定地震 (以下, イベント) に上る損失の確率分 布から対象建物群（以下，ポートフォリオ）のリスクカーブを求める 手法を提案・構築してきた ${ }^{5)}$ 。同手法では, 補填額はイベント毎に求 められるため, ベーシスリスクも確率分布として評価される。

提案するリスクファイナンス手法を用いた地震リスク定量化の手 順を図 1 に示す。

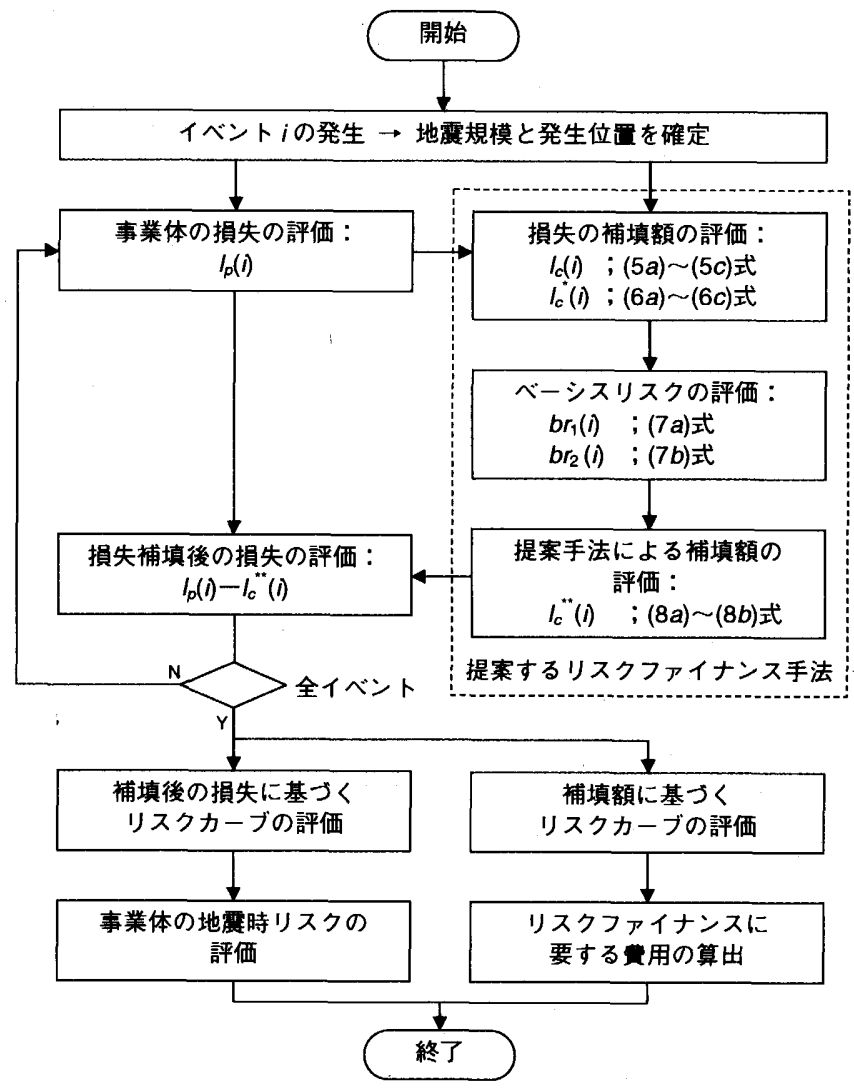

図 1 地震りスク定量化の手順

(1) 損失トリガーによる補填額の算出

イベント $i$ による補填額 $l_{c}(i)$ を次式で与える。

$$
\begin{array}{lll}
l_{c}(i)=0 & \text {, if } & l_{P}(i)<l_{A} \\
l_{c}(i)=l_{P}(i)-l_{A} & \text {, if } & l_{A} \leq l_{P}(i) \leq l_{E} \\
l_{c}(i)=l_{E}-l_{A} & \text {, if } & l_{E}<l_{P}(i)
\end{array}
$$

ここで, $l_{P}(i)$ はポートフォリオの全体の損失， $l_{A}$ は免責額， $l_{E}$ は引 受限度額である。

(2) パラメトリックトリガーによる補填額の算出

パラメトリックトリガーとしては, 地震の発生位置と地震規模の 2 変数を採用する。このとき, イベント $i$ による補填額 $l_{c}^{*}(i)$ を次式で与 える。

$$
\begin{array}{lll}
l_{c}^{*}(i)=0 & \text {, if } M(i)<M_{A} & (6 a) \\
l_{c}^{*}(i)=C \cdot p \cdot f[M(i)] & \text {, if } M_{A} \leq M(i) \leq M_{E} & (6 b) \\
l_{c}^{*}(i)=C \cdot p & \text {, if } M_{E}<M(i) & (6 c)
\end{array}
$$

ここで，M(i)はイベント $i$ のマグニチュード， $M_{A}$ は元本没収が開 始されるマグニチュード， $M_{E}$ は元本没収率が $100 \%$ に至るマグニチ 
ュード, $f[\cdot]$ はマグニチュードと元本没収の関係を規定する関数， $p$ は地震の元本没収の対象となる地震の発生位置を規定する領域(以下, グリッド) から与えられる補填確率，Cは元本である。

(3) ベーシスリスクの算出

イベント $i$ にるベーシスリスクを $b r_{1}(i)$ 及び $b r_{2}(i)$ とすると,これ らは次式で求められる。

$$
\begin{array}{ll}
b r_{1}(i)=l_{c}(i)-l_{c}^{*}(i) & \text { if } l_{c}^{*}(i)<l_{c}(i) \\
b r_{2}(i)=(1-r)\left[l_{c}^{*}(i)-l_{c}(i)\right] & \text {, if } l_{c}^{*}(i)>l_{c}(i)
\end{array}
$$

ここで, $l_{c}(i)$ と $l_{c}^{*}(i)$ は，それぞれ(5)式と(6)式で与えられる補填額て ある。

(4) 提案手法による補填額の算出

(5)式と(6)式で与えられる補填額ならびに(7)式で与えられるべーシ スリスクを用い，次式によりイベント $i$ 毎に補填額 $l_{c}^{* *}(i)$ を評価する。

$$
\begin{array}{ll}
l_{c}^{* *}(i)=l_{c}^{*}(i) & \text {,if } l_{c}^{*}<l_{c} \\
l_{c}^{* *}(i)=l_{c}^{*}(i)-r\left[l_{c}^{*}(i)-l_{c}(i)\right] & \text {, if } l_{c}^{*}>l_{c}
\end{array}
$$

\section{4. 提案手法の有効性検証}

\section{1 諸条件の設定}

(1) モデル事業体

ここでは，図 2 に示すように，南関東地域（1 都 2 県）に 10 棟の 建物群（以下，ポートフォリオ）を有する事業体を想定した。また， 建物の耐震性能および地震時被害額については全建物について同一 とし，福島・矢代 ${ }^{2)}$ に従い，表 2 に示す值を採用した。

\begin{tabular}{|c|c|c|c|}
\hline \multirow{2}{*}{ 被害程度 } & \multicolumn{2}{|c|}{ フラジリティカーブの特性值 ${ }^{*}$} & \multirow{2}{*}{ 被害額 } \\
\hline & 中央值（Gal） & 対数標準偏差 & \\
\hline 小破 & 200 & 0.4 & 5 \\
\hline 中破 & 600 & 0.4 & 10 \\
\hline 大破 & 1000 & 0.4 & 30 \\
\hline 倒壊 & 1400 & 0.4 & 100 \\
\hline
\end{tabular}

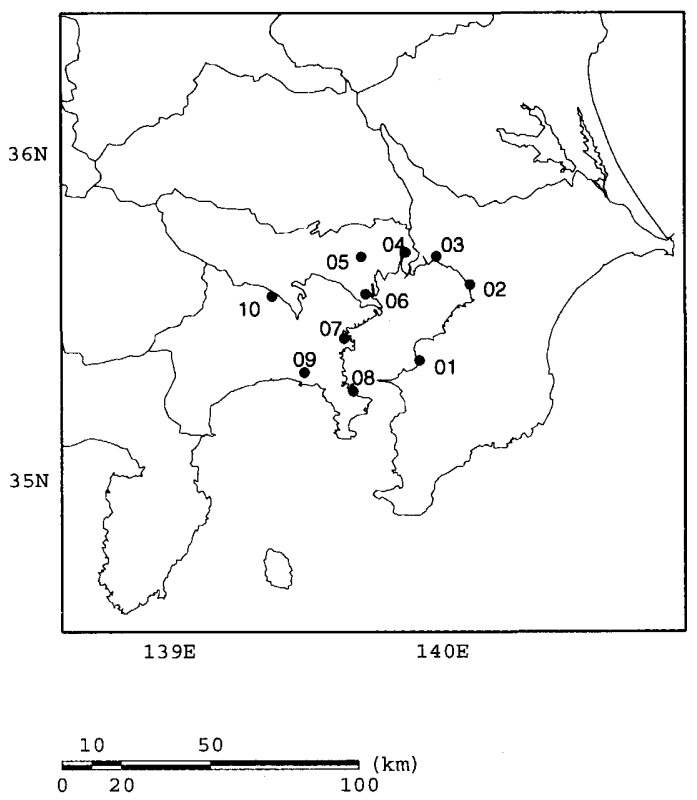

図 2 建物群の配置

表 2 被害程度別のフラジリティ特性値と被害額

\section{(2) 地震環境}

地震活動域モデルについては Annaka \& Yashiro6)を用いて設定した。 大地震発生活動域は, 海域ではマグニチュード 7.5 程度以上, 陸域で はマグニチュード 7.0 以上の地震が繰り返し発生する領域とし, 固有 地震モデルを用いた。中小地震発生活動域についてはグーテンベル グ・リヒターモデルを用い，1885 年 1 月〜1997 年 7 月のマグニチュ 一ド 6 以上の地震数を求め, それに基づき $b$ 值を仮定してグーテンべ ルグ・リヒター式の $\mathrm{Y}$ 切片である $A$ 值を求めた。なお，マグニチュ ード 6 以上の地震が発生していない場合は, 1926 年 1 月 1997 年 7 月のマグニチュード 5 以上の地震数に基づいた。図 3 に設定した地震 活動域を, 表 3 に地震活動域の諸元を示す。

距離減衰式についても同文献に従い，以下の安中式を採用した ${ }^{6}$ 。

$$
\begin{gathered}
\log a=0.61 M+0.00501 h-2.203 \log (d)+1.377 \\
d=\sqrt{\Delta^{2}+0.45 h^{2}}+0.22 \exp (0.699 M)
\end{gathered}
$$

ここに，aは最大加速度 $(\mathrm{cm} / \mathrm{s} / \mathrm{s}), \Delta$ は震央距離 $(\mathrm{km}), h$ は震源 深さ $(\mathrm{km}), M$ はマグニチュードである。距離減衰式のばらつきを 表す対数標準偏差は, 自然対数で 0.5 と設定した。
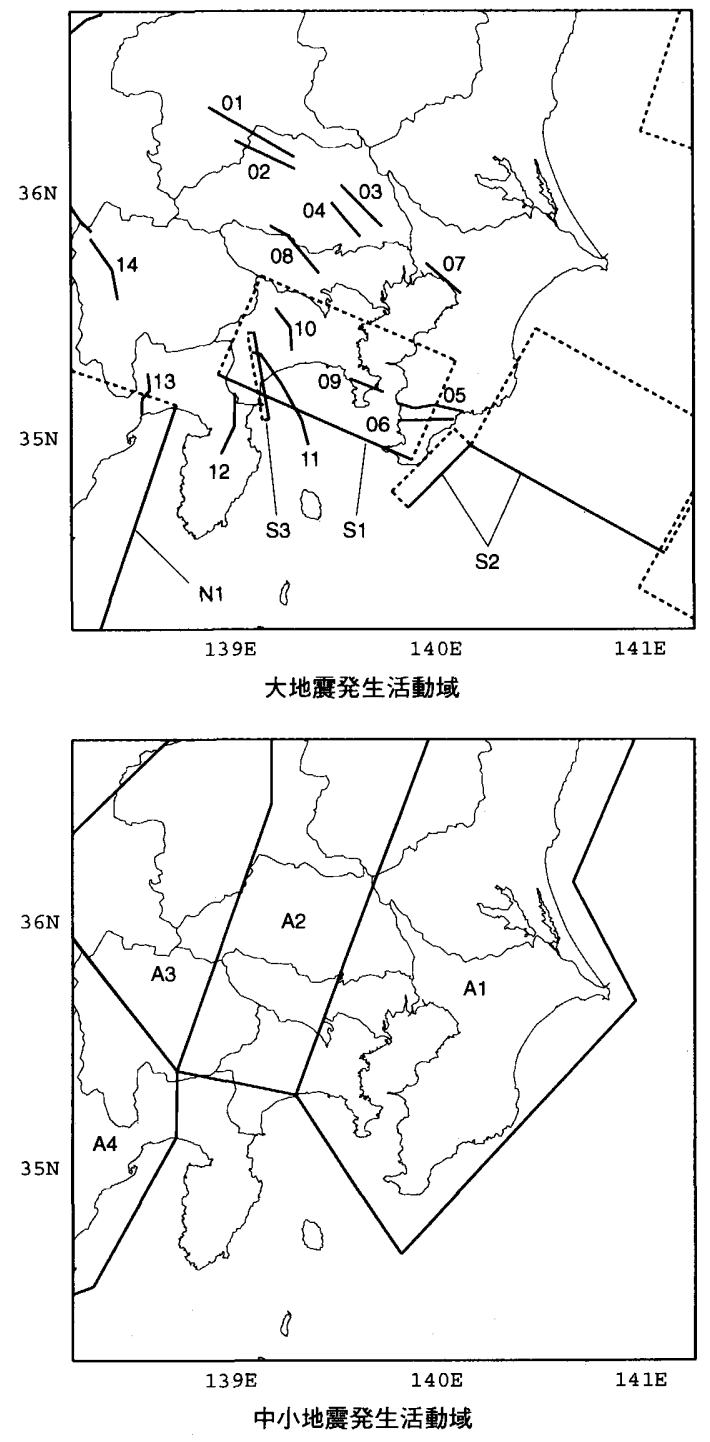

図 3 設定した地震発生活動域 
表 3 地震発生活動域の諸元

\begin{tabular}{|c|c|c|c|c|c|}
\hline $\begin{array}{c}\text { 活動域 } \\
\text { 番量. }\end{array}$ & $M$ の範囲 & $\begin{array}{c}\text { 発生間隔 } \\
\text { (年) }\end{array}$ & $\begin{array}{c}\text { 活動域 } \\
\text { 番号 }\end{array}$ & $M$ の範囲 & $\begin{array}{c}\text { 発生間隔 } \\
\text { (年) }\end{array}$ \\
\hline 01 & $7.0-7.6$ & 1182 & 02 & $6.9-7.3$ & 5212 \\
\hline 03 & $7.0-7.4$ & 79283 & 04 & $6.8-7.2$ & 5931 \\
\hline 05 & $7.1-7.5$ & 2842 & 06 & $7.0-7.4$ & 2639 \\
\hline 07 & $6.8-7.2$ & 5676 & 08 & $7.1-7.5$ & 8710 \\
\hline 09 & $6.6-7.0$ & 1365 & 10 & $6.9-7.3$ & 7239 \\
\hline 11 & $7.5-7.9$ & 1625 & 12 & $7.1-7.5$ & 877 \\
\hline 13 & $6.8-7.2$ & 1917 & 14 & $7.1-7.5$ & 2851 \\
\hline S1 & $7.8-8.2$ & 200 & S2 & $7.8-8.2$ & 1000 \\
\hline S3 & $6.8-7.2$ & 73 & $\mathrm{~N} 1$ & $7.6-8.0$ & 130 \\
\hline $\begin{array}{l}\text { 活動域 } \\
\text { 番号 } \\
\end{array}$ & Mの範囲 & $A$ 值 & $\begin{array}{l}\text { 活動域 } \\
\text { 番号 }\end{array}$ & $M$ の範囲 & $A$ 值 \\
\hline A1 & $5.0-7.0$ & 2.344 & A2 & $5.0-7.0$ & 4.235 \\
\hline A3 & $5.0-7.0$ & 1.645 & A4 & $5.0-7.0$ & 3.344 \\
\hline
\end{tabular}

中小地霞発生活動域の $b$ 值は一律に 0.9 と設定

(3) リスクファイナンス諸元

損失トリガーに係る変数として, 免責額 $l_{A}$ と引受限度額 $l_{E}$ を設定 する。これらは, リスクファイナンスを考慮しない場合のリスクカー ブから設定することとした。前述の条件から得られたりスクカーブを 図 4 に示す。リスクカーブの推定には変動が伴うため, 所与の非超過 確率に対応する損失を結んでフラクタイルリスクカーブとして表現 することが多い。図中の破線は 50\%非超過確率に, 実線は 90\%非超 過確率にそれぞれ対応する。なお, 本研究では, 特に記載しない場合, 90\%非超過確率に対応するものをリスクカーブとして採用する。

$l_{A}$ については比較的短い期間である程度発生すると考えられる損 失を， $l_{E}$ については供用年間中に稀に発生する損失を割り当てた。 具体的には，図 4 に示したリスクカーブから，年超過確率 1/30（20 年 50\%非超過確率に相当)に対応する損失を $l_{A}$, 年超過確率 $1 / 475(50$ 年 $10 \%$ 非超過確率に相当）に対応する損失を $l_{E}$ とし， $l_{A}=13.4$, $l_{E}=107.4$ と設定した。

一方, パラメトリックトリガーに係る諸元として, 元本 $C$, 元本 没収関数, グリッドを設定する。元本は，損失トリガーにおける支払 限度額 $\left(l_{E}-l_{A}\right)$ に等しいものとし， $C=94$ と設定した。

元本没収関数とグリッドに関しては, 提案手法の効果を確認するた

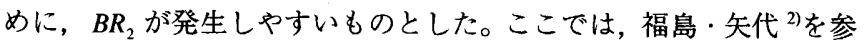
照して, 元本没収関数としては, 図 5 に示すものを採用した。グリッ ドに関しては，図6に示すように，ポートフォリオに外接する長方形 （同図中，細破線で表示）の外側 $50 \mathrm{~km}$ を通る長方形を採用した。

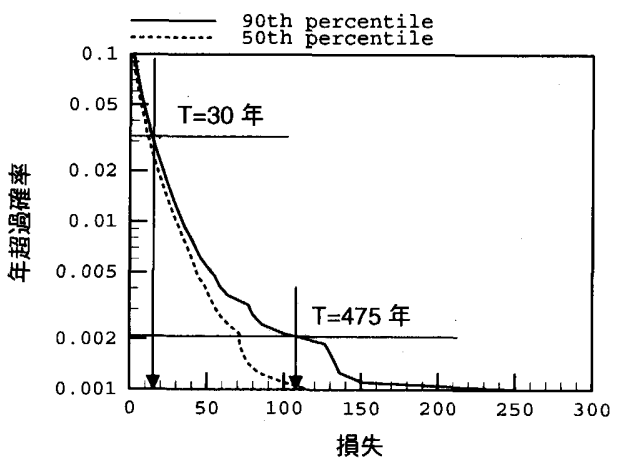

図 4 リスクファイナンスを考虑しない場合のリスクカーブ

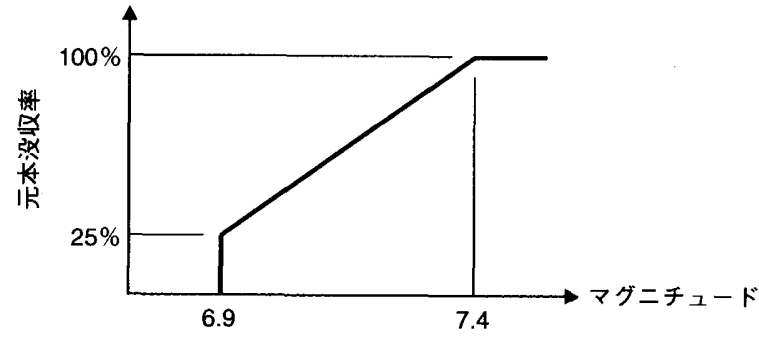

図 5 設定した元本没収関数
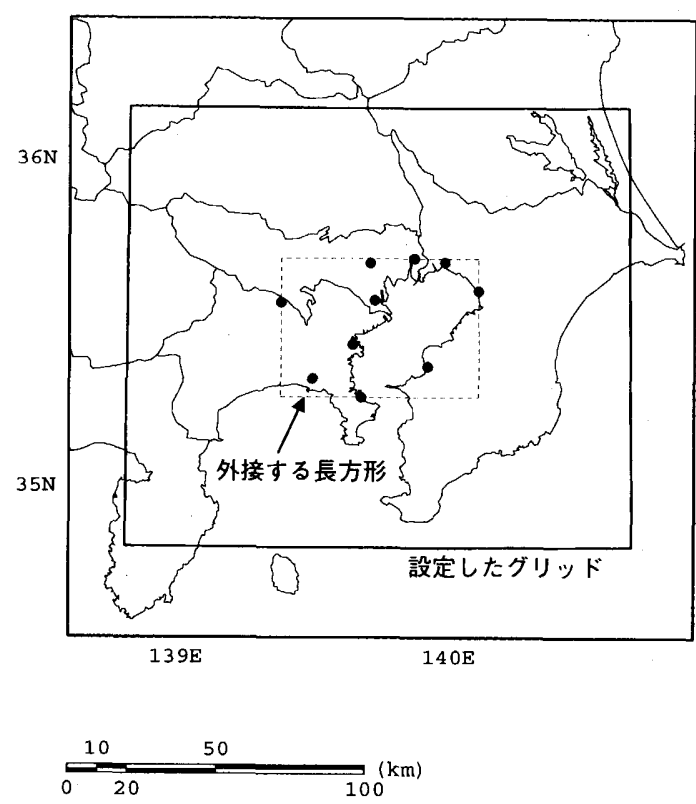

図 6 設定したグリッド

(4) 解析ケース

解析ケースは, 以下の3ケースとした。 ケース 1：損失トリガーによるリスクファイナンス

ケース 2:パラメトリックトリガーによるリスクファイナンス

ケース 3: 提案手法によるリスクファイナンス

\section{2 解析結果}

(1) リスクカーブの比較

図 7 にリクヘッジ側（事業体）とリスクテイク側（事業体のリス クを引き受ける保険会社や一般投資家) のリスクカーブを示す。一点 鎖線はケース 1 を, 破線はケース 2 を，実線はケース 3 を示す。

リスクヘッジ側のリスクカーブにおいてケース 2 をケース 1 と比較 すると, 免責額 $l_{A}=13.4$ 以下では過度に補填されており，免責額以上 では補填が不十分であることがわかる。すなわち,ケース 2 では, $B R_{1}$ と $B R_{2}$ が発生している。これに対し，ケース 3 では，免責額以下で はケース 1 に一致し，免責額以上ではケース 2 に一致することから， $B R_{1}$ のみが発生している。

一方，リスクテイク側のリスクカーブでは，ケース 3 はケース 1 に良く合致しており，損失トリガーと同様のリスク移転が達成できて いると言える。一方, ケース 2 は, 他者と比べて極めて大きく, 過度 のリスク移転になっている。 


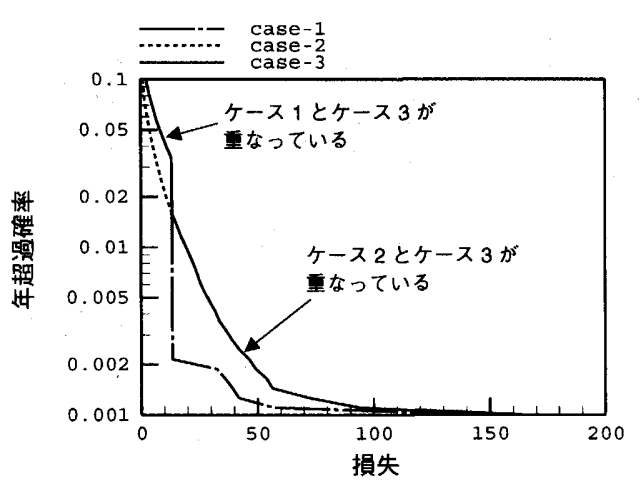

リスクヘッジ側のリスクカーブ

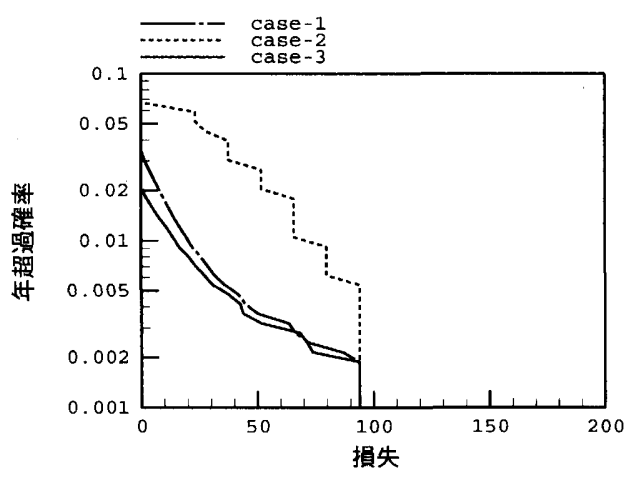

リスクティク側のリスクカーブ

図7 リスクカーブの比較

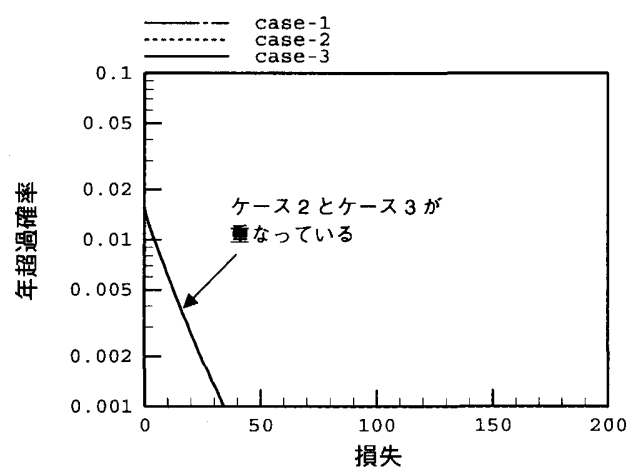

$B R_{1}$ に関するリスクカーブ

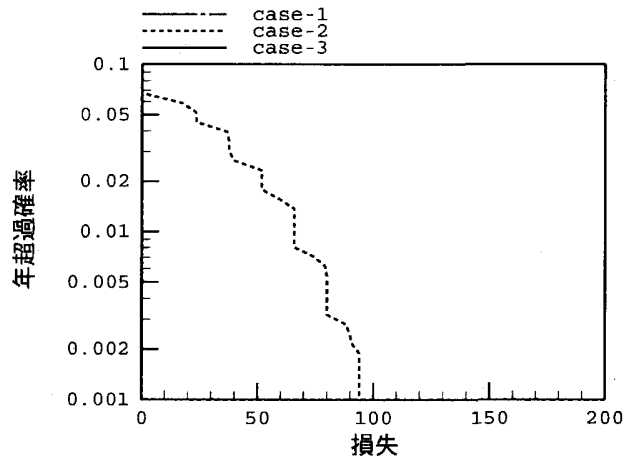

$B R_{2}$ に関するリスクカーブ

図 8 リスクカーブの比較 (ベーシスリスク
図 8 にベーシスリスクに関するリスクカーブを示す。破線はケース 2 を，実線はケース 3をそれぞれ示す。また，定義によりケース 1 に はベーシスリスクは発生しない。

$B R_{1}$ はケース 2 とケース 3 で同一であり, また, $B R_{2}$ が発生しや すいようにパラメトリックトリガーの変数を設定したために,リスク カーブそのものは比較的小さく抑えられている。一方， $B R_{2}$ に関し ては, ケース 3 では発生しないこと, ケース 2 では前述の理由により $B R_{1}$ に比べて大きめになっていることがわかる。

\section{(2) 損失の比較}

図 7 及び図 8 より, 本提案手法は, 従来のパラメトリックトリガー によるリスクファイナンス手法の性能を損なうこと無く, 過度の補填 に係るベーシスリスクの発生を回避できること, その結果として, 過 大なリスクコストの発生を回避できることが明らかとなった。

ここでは, その効果を確認するため，表 4 に解析結果をまとめた。 同表の PML（Probable Maximum Loss）は予想最大損失で, 再現期間 475 年に対応する損失である。また, AEL（Annual Expected Loss）は 年期待損失であり, リスクカーブと座標軸に囲まれる面積として求め られる。AELについては，50\%非超過値を記載している。

ケース 1 では, 引き受け限度額が補填されるため, 結果として免責 額が PML となっている。ケース 2 とケース 3 の PMLは同額であり， $B R_{1}$ が存在するために, 補填額はケース 1 よりは小さい。また, ケー ス 2 では, リスクヘッジ側の AEL が負となっているが，これは，リ スクファイナンスによって利益が発生していることを示すものであ る。この不合理さはケース 3 では解決されている。

リスクテイク側の PMLの差異は大きくはないが, AELについては ケース 2 が極めて大きい。リスクコストがリスクテイク側の AELに 比例すると仮定するならば, 提案手法により, 大幅にリスクコストを 低滅することが可能となる。

\begin{tabular}{|c|c|c|c|c|}
\hline \multirow{2}{*}{$\begin{array}{c}\text { リスク } \\
\text { ファイナンス }\end{array}$} & \multicolumn{2}{|c|}{ リスクヘッジ側 } & \multicolumn{2}{|c|}{ リスクテイク側 } \\
\hline & PML & AEL & PML & $\mathrm{AEL}$ \\
\hline なし & 107.4 & 1.420 & - & - \\
\hline ケース 1 & 13.4 & 0.906 & 92.8 & 0.511 \\
\hline ケース 2 & 47.1 & -1.614 & 94.0 & 3.033 \\
\hline ケース 3 & 47.1 & 1.040 & 75.8 & 0.376 \\
\hline
\end{tabular}

\section{5. リスクコストに基づく提案手法の実現可能性}

5.1 リスクプレミアムを考慮したリスクファイナンス条件の設定

(1) リスクプレミアムの必要性

本手法では， $B R_{2}$ は手法の性質上発生せず， $B R_{1}$ はパラメトリッ クトリガーの変数の設定により原理的には 0 とすることが可能であ る。すなわち, 前章で示したとおり, 本提案手法はパラメトリックト リガーによる利点を有したまま, 損失トリガーによるリスクファイナ ンスを実現するものである。

ところで, 上記の優位点は, 復旧費用の見積もり後に過分な資金を 一般投資家に返却可能であることを前提としている。これは, 事業体 にとって都合が良い反面,一般投資家にとっては一時的ではあるが元 本が過大に没収されるというリスクが伴う。したがって，そのリスク 
に見合うプレミアムが要求されることは自然である。また，本提案手 法がオプション取引的であることは前述したが,その意味でもオプシ ヨン料に相当するプレミアムは必要である。

\section{(2) リスクプレミアムの定式化と補填額}

一時的な徵収金の額が大きいほど,リスクプレミアムが大きくなる とするのは自然である。そこで本研究では, 最も単純な例として, リ スクプレミアム $R P$ を变換額の関数として次式で表すこととした。

$$
R P=s\left(l_{c}^{*}-l_{c}\right)
$$

ここで， $s$ はリスクプレミアムを規定する定数で， $0.0 \leq s \leq 1.0$ とす る。

復旧費用の見積もり後，一般投資家に $R P$ を返却するためには，返 却分を含んだ形で補填額 $l_{c}^{* *}$ を設定すれば良い。例えば，(8)式は，次 式のように書き直すことができる。また，(11)式による補填方法を図 示したものが図 9 である。

$$
\begin{array}{ll}
l_{c}^{* *}(i)=l_{c}^{*}(i) & \text {,if } l_{c}^{*}<l_{c} \\
l_{c}^{* *}(i)=l_{c}^{*}(i)-(r-s)\left[l_{c}^{*}(i)-l_{c}(i)\right] & \text {, if } l_{c}^{*}>l_{c}
\end{array}
$$

(11b)式において， $s=0.0$ とした場合には 4 章の例題におけるケー ス 3 に等しくなり,リスクテイク側は過大没収に関連するリスクプレ ミアムを受け取ることはできない。一方， $s=1.0$ とした場合にはヶ ース 2 に等しくなり,リスクヘッジ側の優位性が失われる。 $s>1$ の 場合には，むしろ従来手法を採用することが適切である。

したがって, 図 9 において $0.0<s<1.0$ となる $s$ を採用することで, リスクヘッジ側とリスクテイク側の双方に優位性を与えることがで きる。すなわち，リスクヘッジ側はPMLの低隇効果を損なうことな く,パラメトリックトリガーと損失トリガーの優位性を併せ持ったリ スクファイナンスが可能である。また，リスクテイク側は，本来負う ベきリスクに見合ったリスクプレミアムに加えて, 後に返却される元 本についてのリスクプレミアムを得ることができる。

なお，両者にとっての優位性は $s$ を変数としてトレードオフの関係 にあるものの, その最適値を得ることは可能であると考える。

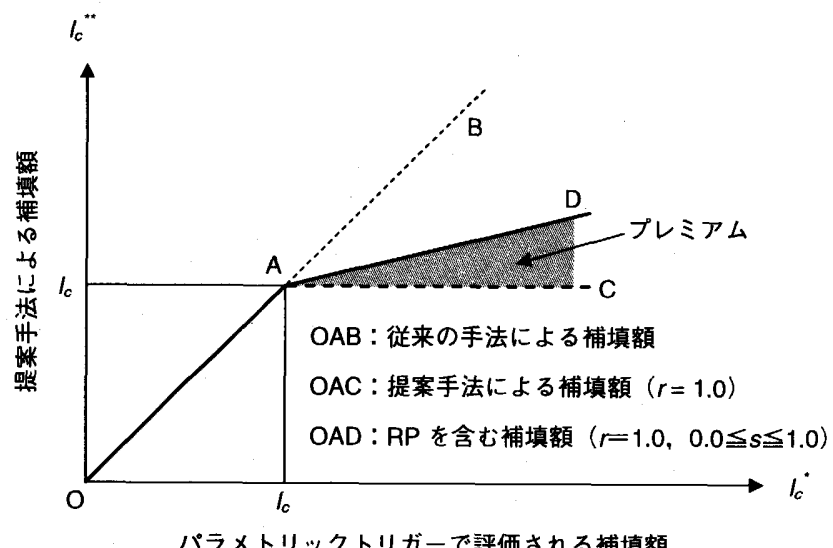

図 9 リスクプレミアム（RP）を含んだ補填額の設定

\section{2 解析条件}

\section{（1）モデル事業体と地震環境}

モデル事業体及び地震環境は，4章で採用したものを踏襲する。し たがって, 事業体を構成する建物の配置と諸元は, 図 2 と表 2 に示さ れているものと同一である。震源モデルとその諸元は, 図 3 と表 3 に示されているものとし, 距離減衰式は(9)式で示す安中式とした。

\section{(2) リスクファイナンス手法と諸元}

リスクファイナンス手法は提案手法とし，その諸元である，元本， 元本没収関数, グリッドは，4 章と同一とする。リスクプレミアムを 規定する定数 $s$ については，解析変数とし，0.0〜1.0 まで，0.1 刻み で与えた。

\section{3 解析結果}

(1) リスクカーブの比較

図 10 にリスクテイク側のリスクカーブ及び $B R_{2}$ のリスクカーブを 示す。なお, 図 9 に示したように, 最終的にリスクヘッジ側が得る補 填額は $s$ に関わらず同一であること，また， $B R_{1}$ はその定義により， やはり $s$ に関わらず同一であることからこれらに対するリスクカー ブは図 7 及び図 8 に示したものと同一である。

$s$ が大きくなるに従い, 本提案手法によるリスクカーブ（図 7 及び 図 8のケース 3) から，従来の手法によるリスクカーブ（同，ケース 2）に近づいていく。また，BR，のリスクカーブが与える所与の年超 過確率での損失は $s$ と比例関係にあることがわかる。任意の $s$ に対す るリスクカーブと， $s=0$ に対するリスクカーブの差は，その定義に より $B R_{2}$ のリスクカーブに等しいことから， $\mathrm{AEL}$ の増分は $s$ と比例 関係にある。

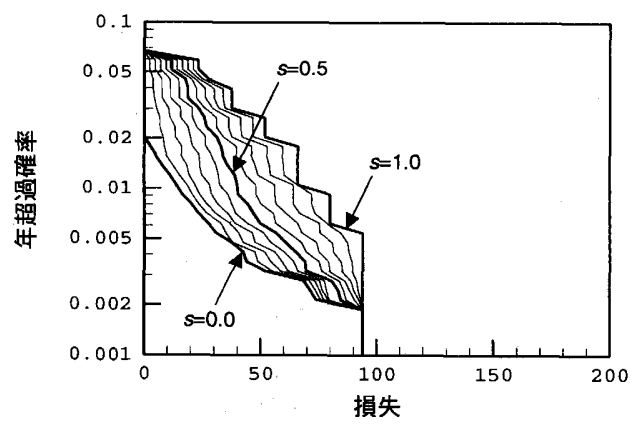

リスクティク側のリスクカーブ

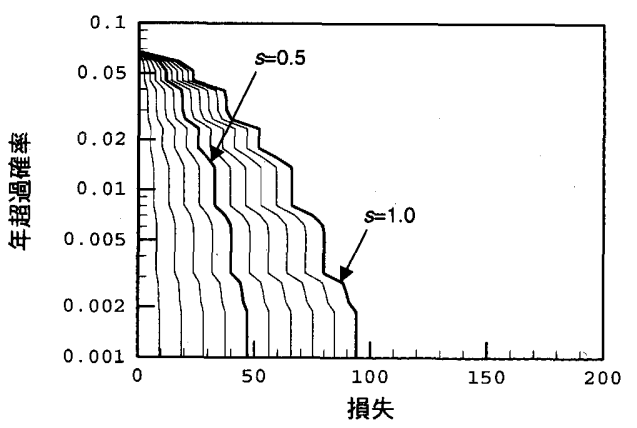

$B R_{2}$ に関するリスクカーブ

図10 リスクカーブの比較 


\section{(2) 変数 $s$ と規準化 AEL}

変数 $s$ がリスクプレミアムに与える影響を検討するため, $s$ に対す る規準化 AELの值を整理した。ここで, 規準化 AEL とは, 図 7 のケ 一ス 3 に対応したリスクカーブから得られる AELに対する他の AEL の比と定義する。また，リスクコストが AELに比例すると考えるの ならば, 規準化 AEL は, 本提案手法において, $(r, s)=(1.0,0.0)$ とい う条件で得られるリスクコストに対する,他の条件でのリスクコスト の比と考えることもできる。

図 10 に示した 2 種類のリスクカーブについて求めた $s$ と規準化 AELの関係を図 11 に示す。表 4 にも示しているが提案手法と従来手 法では, AEL で 8 倍強の差がある。リスクプレミアムの設定として, 例えば, 地震リスクの証券化等では LIBOR (London Inter-Bank Offered Rate：ロンドン銀行間取引利率）+3\%としているが2), 仮に $10 \%$ とし ても規準化 AEL は従来手法のものに比べて十分小さいことがわかる。 以上のことは, リスクヘッジ側及びリスクテイク側にとって，十分 に魅力あるリスクファイナンス手法であることを示している。

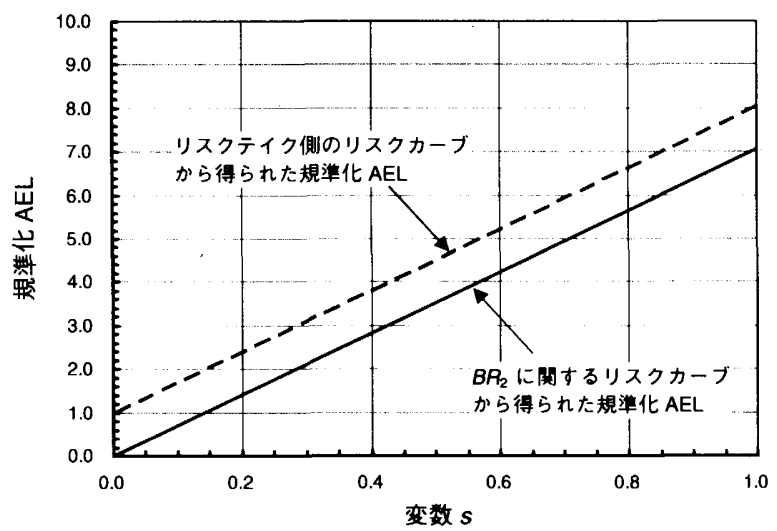

図 11 変数 $s$ と規準化 AEL の関係

\section{5. まとめ}

本研究では, 被災後の迅速な資金調達を目的に, パラメトリックト リガーによるリスクファイナンス手法を基本として,ベーシスリスク 低減の観点から新たなリスクファイナンス手法を提案・構築した。さ らに, 南関東地域に複数の建物を有する仮想の事業体を設定し, 本提 案手法の有効性や実現性に関する検討を行い，以下の結論を得た。

1) 本提案手法によれば, 従来の地震保険と同様のリスク移転が可 能となり，結果として，ベーシスリスクを十分小さく抑えるこ とができる。

2）本提案手法は，過度の補填を避けることができるために，従来 の手法に比較してリスクテイク側のリスクを大幅に低減でき， 大幅にリスクコストを低減することができる。
3）本手法によるリスクヘッジ側のリスクの増大は, 高頻度・低額 の損失部分にのみ現れるため, 事業体はそれを保有することが 十分可能である。また，リスクマネジメントで対象とするよう な低頻度・高額の損失については, 従来手法と同一の性能を有 している。

4) 元本の一時的な没収に対してリスクプレミアムを支払うとい う枠組みは，一般投資家にとっては十分魅力的であり，また， 事業体にとっても，従来手法に比べれば十分に小さいリスクコ ストでリスクファイナンスができるという点で望ましいもの である。

ここで提案した手法は, 被災後の支払いの迅速さという面で, 従来 のパラメトリックトリガーによるリスクファイナンスの利点を有し， リスクコストの低さという面で, 従来の損失トリガーによるリスクフ アイナンスの利点を有している。地震リスクの証券化に代表されるよ うなパラメトリックトリガーによるリスクファイナンスが, そのリス クコストの大きさのために十分な普及に至っていない点を鑑みると， 本手法は,パラメトリックトリガーによるリスクファイナンスの普及 に大いに資するものであり，事業体の業務再開の迅速化と経済被害の 軽隇に繋がるものであると考える。

今後は,証券化やリスクスワップといったりスクファイナンス手法 への具体的な適用方法とともに, 本手法を適用することによる事業継 続性についても検討を行う予定である。

注

注 1）地震保険：地震に関する損害保険には，住宅を対象とする地震保険と， 事務所ビルや.[場等を対象とし火炎保険の特約として契約する火災保 険搪張担保特約がある。本研究で扱う保険は後者になるが，論文中では 「地震保険」として記述する。

\section{参考文献}

1) 内閣府：事業継続ガイドライン 第一版 - わが国企業の減災と災害対応の 向上のために -, 内閣府 HP

(http://www.bousai.go.jp/MinkanToShijyou/guideline01.pdf)

2）福島誠 郎, 矢代晴実：地震リスクの証券化に扔ける条件設定に関する解 析, 日本建筑学会計画系論文集, No.555, pp.295-302, 2002.5

3) 矢代晴実, 福島誠一郎, 都築充雄：地震リスクスワップの成立性と条件設 定に関する研究，日本建築学会環境系論文集, No.586, pp.107-114, 2004.12

4) 矢代晴実, 佐藤一郎, 福島誠一郎, 上田三夫:地震りスクデリバティブにお けるベーシスリスクに関する研究 (その1:ベーシスリスクの考え方), 日 本建築学会大会学術講演梗概集 F-1 分冊, pp.1359-1360, 2004.8

5）福島誠一郎，矢代睛実：地震ポートフォリオ解析による多地点に配置され た建物群のリスク評価, 日本建築学会計画系論文集, No.552, pp.169-176, 2002.2

6) T. Annaka and H. Yashiro : A seismic source model with temporal dependence of large earthquake occurrence for probabilistic seismic hazard analysis in Japan, Risk Analysis, WIT PRESS, pp.233-242, 1998 